\title{
Implementation of the United Nations Security Council Resolution under the Indonesian Legal System
}

\section{Sefriani* \& Nur Gemilang Mahardhika** $^{* *}$}

Today, the question on the legal instruments of international organisations that impose direct sanctions on individuals and legal entities have surfaced, such as the United Nations Security Council (UNSC) Resolutions. States are obliged to implement the UNSC Resolutions but would face difficulties in this course. The UNSC's coercive approach rubs international security against democratic legitimacy, especially when the Resolutions violate due process of law, principle of legality and human rights. To date, Indonesia's stance on international law (including UNSC Resolutions) under its legal system remains unclear. This study analyses the implementation of the UNSC Resolutions in Indonesia, which has no uniformity without a UN Act. The case of North Korean vessel, MV Wise Honest, highlights the growing confusion in Indonesia because violation of the UNSC Resolutions has not been governed. Conclusively, Indonesia needs to enact a UN Act to provide legal certainty in the implementation of the UNSC Resolutions.

\section{Keywords}

MV Wise Honest, Indonesia, North Korea, Targeted Sanction, UNSC Resolution, UN Act

* Corresponding Author. Professor of International Law at Universitas Islam Indonesia. S.H./LL.B. (Gadjah Mada U.), M.Hum. /LL.M. (Padjadjaran U.), Ph.D. (Gadjah Mada U.). ORCID: http://orcid.org/0000-0003-1192-5183. The author may be contacted at: sefriani@uii.ac.id/Address: Faculty of Law Universitas Islam Indonesia, Taman Siswa St. No. 158, Yogyakarta, Indonesia, 55151.

** Junior Lecturer in Public International Law at Universitas Islam Indonesia. S.H./LL.B.(U. Islam Indonesia), LL.M. (Melb.). ORCID: http://orcid.org/0000-0003-2047-7757. The author may be contacted at: gemilang.mahardhika@uii.ac.id/Address: Faculty of Law Universitas Islam Indonesia, Taman Siswa St. No. 158, Yogyakarta, Indonesia, 55151.

All the websites cited in this article were last visited on November 1, 2021. 


\section{Introduction}

In April 2018, a North Korean cargo vessel, the MV Wise Honest was moored at Balikpapan Navy Base. The vessel which was loaded with 26,500 metric tons of coal was charged with violating the Indonesian Immigration Law and the Shipping Law. The alleged violations read as: turning off the Automatic Identification System (AIS); covering the vessel's name; sailing with flags of two different nations of Sierra Leone and North Korea; and transporting coal from Russia without legitimate exportimport documents. ${ }^{1}$ The court sentenced the vessel, to pay a fine of 400 million IDR. ${ }^{2}$ After the execution was carried out, however, the Ministry of Law and Human Rights received an Mutual Legal Assistance (MLA) request from the US Department of Justice on July 20, 2018 to provide assistance with the seizure of the MV Wise Honest in relation to the ongoing investigation process of alleged money laundering and violations of the UNSC Resolutions 1718 (2006), 2270 (2016) and 2731 (2017). ${ }^{3}$

It was difficult for Indonesia to respond to the MLA request as violations of the UNSC Resolutions are not considered as criminal acts in the country. ${ }^{4}$ Indonesia is yet to have UN-related law-or what is commonly known as the UN act. The UN act is useful for implementing the Security Council resolutions into Indonesian municipal law. Even though as a UN member, Indonesia should transform the UN resolution into national law in order to implement it. On April 11, 2019, the vessel was eventually handed over to the US authorities. The aforementioned series of procedures undertaken by the Indonesian law enforcers, however, were actually not in response to the violation of the UNSC Resolution, but rather in accordance with the Indonesian Immigration Law and the Shipping Law. The UNSC Resolutions 1718 (2006), 2270 (2016) and 2371 (2017) prohibit the UN members from conducting sale and purchasing or transferring a number of commodities including coal to

1 See Balikpapan District Court Decision No. 682/Pid.B/2018/PN.BPP, https://putusan3.mahkamahagung.go.id/ direktori/putusan/602fe8eb61d39af4eebce7e92e69e455.html.

2 D. Septiari \& N. Adri, Indonesia 'Sought Balance' in Handling of North Korean Vessel, Jakarta Post, June 18, 2019, https://www.thejakartapost.com/news/2019/06/18/indonesia-sought-balance-in-handling-of-north-korean-vessel.html. For details, see United States of America v. The Bulk Cargo Carrier Known as the "Wise Honest," Bearing International Maritime Organization Number 8905490, https://www.justice.gov/opa/press-release/file/1161356/download.

3 Id. See also S. Guraba, Kedudukan Resolusi DK PBB dalam Sistem Hukum Indonesia [The Position of UN Security Council Resolutions in the Indonesian Legal System], Hukum OnLIne (Nov. 2020), https://Www.Hukumonline. Com/Berita/Baca/Lt5fa26fda02e3c/Kedudukan-Resolusi-Dk-Pbb-Dalam-Sistem-Hukum-Indonesia-Oleh--SakafaGuraba?Page=3.

4 A. Sobari, MLA in Criminal Matters as Asset Recovery's Tool, 26(2) MimBar HuKum 305 (2014), https://jurnal.ugm. ac.id/jmh/article/download/16049/10595. 
and from North Korea. These sanctions were imposed as a result of North Korea's repeated nuclear tests and the launch of intercontinental ballistic missiles ${ }^{5}$ which are categorized as threatening international peace and security.

This confusion occurs in the implementation of not only the UNSC Resolutions against North Korean ships, but various other Resolutions. For instance, the implementation of the UNSC Resolution 1267 (1999) on Financing of Terrorism ${ }^{6}$ and its derivatives, such as Resolutions 1333, 1337, 1363, 1373, 1390, 1452, 1455, 1526, 1566, 1617, 1624, 1699, 1730, 1735, 1822 and 1904. Resolution 1267 and its derivatives are referred to as targeted sanctions because sanctions in the form of asset freezing, travel bans and embargoes aim directly at individuals or entities suspected of contributing to financing or being linked to terrorist networks. ${ }^{7}$ The targeted sanctions model is intended to overcome the weaknesses of the traditional sanctions model. The UNSC's collective sanctions against Iraq after Iraq's aggression in Kuwait, are believed to be unfair sanctions, harming the civilians, and posing a severe impact on the most vulnerable segments of the population. ${ }^{8}$ The UNICEF and "Save the Children" argue that those sanctions have devastated civic communities in Iraq causing the deaths of thousands of people, young and old. ${ }^{9}$ This finally prompted the UNSC to adopt nonmilitary sanctions, namely in the form of targeted sanctions. ${ }^{10}$

Nonetheless, this new type of sanction has been criticized by the international community as it does not meet the globally accepted criterion such as due process of law, thereby indirectly forcing the state to choose between national and international law-the obligation to comply with the UNSC Resolutions as requested by Article 25 of the UN Charter. ${ }^{11}$ To date, Indonesia does not have a legal umbrella specifically regulating the implementation of the UNSC Resolution. In case of sanctions aimed directly at individuals or legal entities under the national jurisdiction, especially, such absence would cause legal uncertainty in its actual implementation. Moreover,

5 North Korea conducted a nuclear weapons test on January 6, 2016 and ballistic missile tests on July 3 \& 28, 2017.

6 J. Genser \& K. Barth, When Due Process Concerns Become Dangerous: The Security Council's 1267 Regime and the Need for Reform, 33 B.C. InT'L \& Comp. L. Rev. 1-2 (2010).

7 J. Garvey, Targeted Sanctions: Resolving the International Due Process Dilemma, 50 Tex. InT'L L.J. 551 (2016).

8 R. Normand, Iraqi Sanctions, Human Rights and Humanitarian Law, MERIP (Sept. 1996), https://merip.org/1996/09/ iraqi-sanctions-human-rights-and-humanitarian-law. See also D. Koller \& M. Eckenfels-Garcia, Using Targeted Sanctions to End Violations against Children in Armed Conflict, 33(1) B.U. InT'L L. J. 6-8 (2015), https://www. corteidh.or.cr/tablas/r33548.pdf.

9 G. Willis, Security Council Targeted Sanctions, Due Process and the 1267 Ombudsperson, 42 Geo. J. Int'L L. 676 (2011).

10 Id.

11 U.N. Charter art. 25 states: "...the Members of the United Nations agree to accept and carry out the decisions of the Security Council in accordance with the present Charter." For details, see Genser \& Barth, supra note 6, at 8. 
a question may arises: when a resolution violates the rights of individuals and legal entities protected by the law and the constitution, which should prevail between national law or the UNSC Resolution?

This research aims to provide in-depth analysis on the implementation of the UNSC Resolutions under the Indonesian legal system. This paper will describes the position of the UNSC Resolution in international law and national law; discuss the targeted sanctions in the UNSC Resolutions as the best practice of the international community in implementing the UNSC Resolutions; examine the Indonesia's practices related to the implementation of the UNSC Resolutions; and suggest the way to the most efficient and legitimate implementation of the UNSC Resolutions under the Indonesia's national legal system.

\section{Targeted Sanctions in the UNSC Resolutions}

Resolutions 1267 and 1373 imposed direct sanctions on the targeted individuals and entities who were considered to involve in terrorist networks. ${ }^{12}$ This targeted sanctions model is also applied by the Security Council to address other critical challenges to the international legal order, such as the proliferation of weapons of mass destruction, drug trafficking, and money laundering. In particular, the model of economic sanctions on individuals or entities that have been the targeted by Resolution 1267 is expected to damage their finances. The targeted sanctions model is expected to prevent other losses to the public in general, but carry out pinpointing sanction against the targeted ones. ${ }^{13}$

The types of the said sanctions include: asset freezing, travel bans, arms embargoes, commodity bans, transportation bans, diplomatic restrictions, bans on proliferation-sensitive goods, and financial restrictions. ${ }^{14}$ The targeted sanction, however, has clashed with the some double procedures of national law which require legal rules before coercive measures are imposed on individuals or corporations. ${ }^{15}$ In addition, it has made a conflict between the implementation of the UNSC Resolutions

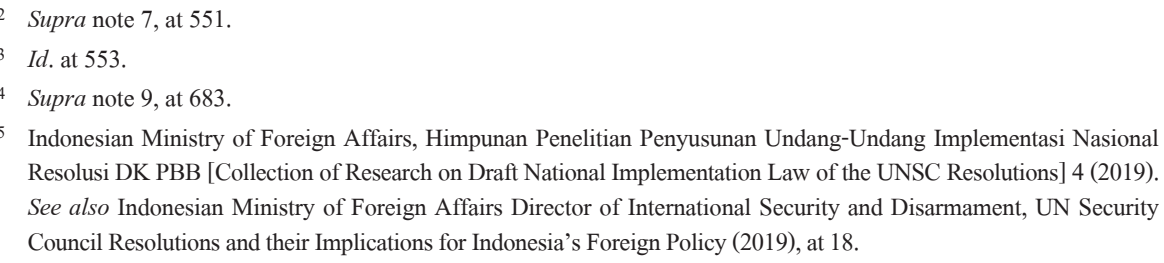


for the global security and the constitutional rights and obligations of individuals or corporations within the national jurisdictions. ${ }^{16}$

In its implementation, Resolutions 1267 and 1373 were criticized for violating due process of law. ${ }^{17}$ Those who were included in the consolidated list of the 1267 Committee with neither prior notification nor a court decision, were not given the opportunity to challenge the listing. Responding to this criticism, a procedural mechanism is hence provided to add or delete the names of individuals or legal entities listed in the 1267 Sanction Committee Blacklist as regulated in the UNSC Resolution 2368 (2017). ${ }^{18}$ Improvements to this mechanism are also stated in Sections 4 and 6 of the United Nations Al-Qaeda and Taliban Sanctions Committee Guidelines No. 1967. ${ }^{19}$ Furthermore, Resolution 2560 (2020) was adopted to improve the working method of the 1267 Sanctions Committee. Resolution 2560 emphasizes the importance of developing and maintaining security, while respecting human rights under the UN Charter and other international laws in the course of combating terrorism. ${ }^{20}$

\section{The UN Decisions for Sanctions}

The UNSC's resolutions to impose sanctions are categorized as an action rather than as a treaty. According to Dixon, the UNSC Resolution is more of a mandatory enforcement action against delinquent states. ${ }^{21}$ Article 25 of the UN Charter states that UN Resolutions are binding on member states. It means that the UNSC Resolutions under Chapter VII of the Charter must be implemented immediately at the national level without the need for a scrutiny stage such as the ratification of the head of

16 Id. at 5.

17 J. Suri, The United Nations Security Council Resolution on Sanctions Towards Individual from the Perspective of International Law, 3(2) Padjadjaran J. Int'L L. 202 (2019); C. Michaelsen, Kadi and Al-Barakaat v Council of the European Union and Commission of the European Communities: The Incompatibility of the United Nations Security Council's 1267 Sanctions Regime with European Due Process Guarantees, 10 MelB. J. InT'L L. 329 (2009); T. Biersteker, Targeted Sanctions and Individual Human Rights, 65 (1) InT'L J. 103 (2009).

18 U.N. Doc. S/RES/2368 (2017), ๆๆ 1-9 \& 50-59. Consolidated list can be seen on https://www.un.org/securitycouncil/ content/un-sc-consolidated-list. C. Portela, National Implementation of UN Sanction toward Fragmentation, 10 INT'L J. 16 (2009), https://cadmus.eui.eu/bitstream/handle/1814/14437/International_Journal_Portela.pdf.

19 Security Council Committee pursuant to Resolutions 1267 (1999), 1989 (2011) and 2253 (2015) concerning ISIL (DA'ESH), Al-Qaida and Associated Individuals Groups Undertakings and Entities, "Procedures for Listing," https:// www.un.org/securitycouncil/sanctions/1267.

20 U.N. Doc. S/RES/2560 (2020), ๆ 8, https://undocs.org/S/RES/2560(2020).

21 M. Dixon, Text Book on International Law 47-8 (4th ed. 2000). 
state. $^{22}$ Actually, the UNSC Resolution is not a self-executing treaty because it is not adopted by general negotiation process. However, its implementation shall immediately ignore domestic procedures. ${ }^{23}$

Meanwhile, there are three types of the UN action that affect the national legal systems of member States, which are: ${ }^{24}$ first, the legislative action such as multilateral conventions that require the signature or ratification of its members; ${ }^{25}$ second, the executive actions legally binding on the members such as the UNSC Resolution based on Article 41 of the Charter; ${ }^{26}$ and third, the executive actions with a direct effect on the rights and duty of individuals or legal entities of member States. ${ }^{27}$

For example, the UNSC Resolution 827 (1993) established an International Tribunal for prosecuting the persons responsible for serious violations of international humanitarian law committed in the territory of the former Yugoslavia since 1991 following the Statute of the International Criminal Tribunal for the former Yugoslavia (ICTY). ${ }^{28}$ The jurisdiction ratione personae of the ICTY is addressed to all natural persons responsible for serious violations of international humanitarian law committed in the territory of the former Yugoslavia since 1991, regardless of their nationality. However, it is not easy to directly implement this resolution at the national level. In Japan, for example, to implement Resolution 827, a habeas corpus warrant and the fulfilment of the principle of nullum crimen sine lege as guaranteed under the Japanese Constitution are required. ${ }^{29}$ The problem will be more complex when this resolution is deemed to infringe the constitutional principles of the member States such as the due process of law.

\section{The Practice of States and International Courts}

Several countries, such Switzerland, Sweden, Germany, the UK, the US Australia,

22 Indonesian Ministry of Foreign Affairs, supra note 15, at 6.

23 Id.

24 H. Owada, International Organizations and National Law, 89 Proc. Am. Soc'y Int'L L. Annual Meeting: Structures OF WORLD ORDER 255 (1995), https://www.jstor.org/stable/25658920?refreqid=excelsior\%3A0a28283868d707dc9dc28 c671f421ead.

25 Id.

$26 I d$. at 256.

27 Id.

28 U.N. Doc. S/RES/827 (May 25, 1993), https://undocs.org/en/S/RES/827(1993).

29 Id. 
Germany, Japan, the Netherlands, Singapore, and India have already enacted their own law on the implementation of the UN Resolutions, which are often referred to as the "UN Act.",

\section{A. Japan}

Japan adheres to the theory of non-self-executing actions of international organisations such as the UNSC Resolutions, in which Japan will first ensure the validity of the said resolutions in its national legal system. If the resolutions can be realized through the existing laws at the national level in Japan, no further legislative steps are needed for implementing this obligation. Unless the new obligations arising from the executive action can be carried out in its existing legal system, however, a new law should be enacted to implement such action of the organisation. Relevant examples in this regard include Article 52 of the Foreign Exchange and Foreign Trade Control Law and Article 3 of the Import Control Order which authorize the Minister of Trade and Industry to take necessary export and import restrictions as required by the UNSC. ${ }^{31}$

\section{B. The Netherlands}

The Netherlands has the 1977 Sanctiewet (Law on Sanctions) ${ }^{32}$ as the legal basis for implementing the UNSC Resolutions at the national level. The 1977 Sanctiewet is also used to enforce a binding decision (directive) of the European Union. ${ }^{33}$ In implementing the coercive measures of the UNSC Resolutions, the 1977 Sanctiewet would authorize the Minister of Foreign Affairs to set ministerial orders or trade embargo decisions. The Minister of Foreign Affairs can delegate it to the relevant Ministries or Institutions to impose restrictions on the traffic of goods (export-import), services, and investment with the subject country, including telecommunications. The 1977 Sanctiewet was amended several times to accommodate the need for implementing economic sanctions related to financial transactions. ${ }^{34}$

30 Portela, supra note 18, at 13. See also R. Suhendar, Penerapan Resolusi Dewan Keamanan Perserikatan Bangsa-Bangsa (DK PBB) dalam Hukum Nasional Indonesia [Implementation of the UNSC Resolutions in Indonesian National Law], 25 OPINIO JURIS 15-7 (2019), https://treaty.kemlu.go.id/uploads/images/jurnal/jurnal-5e1d73377177c.pdf.

31 Supra note 24, at 257.

32 Sanctiewet 1977, art. 93, https://wetten.overheid.nl/BWBR0003296/2020-05-21.

33 J. Joackim \& B. Verbeek, International Organizations and Policy Implementation: Pieces of the Puzzle, in International Organizations and Implementation: Enforcers, MANagers, Authorities 3-16 (J. Joachim et al. eds., 2008).

34 Council of Europe, The Implementation of United Nations Sanctions-Contribution of Netherlands, CAHDI Database (Mar. 1, 2006), http://www.cahdidatabases.coe.int/Contribution/Details/55. 


\section{Singapore}

Singapore has enacted its UN Act (Chapter 339) which is intended to implement Article 41 of the UN Charter related to the measures not involving the use of armed forces, in particular apprehension and trial, as well as financial measures against individuals or groups who finance terrorism..$^{35}$ An example is the UNSC Resolution 1373 which obliges the states to draw up a national list of individuals or entities of terrorist groups. Before 2001, the UNSC Resolutions were implemented on a case-bycase basis that took a long time and lacked in legal certainty. A number of domestic provisions before the UN Act were deemed insufficient for the implementation of the UNSC Resolutions. The existing national legislation is only capable of freezing the assets of Singaporean citizens involved in domestic funding. ${ }^{36}$

Today, Singapore faces at least two issues in its domestic implementation of the UNSC Resolutions, namely, the duration in implementing the UNSC Resolutions and the implementation of New Legal Rules. ${ }^{37}$ Currently, the UN Act serves as the legal umbrella to assist in transforming the UNSC Resolution into Singapore's national law for implementation without hesitation. Commonly in the dualist State, ${ }^{38}$ the UN Act is needed as the legal basis for implementing non-self-executing international instruments such as the UNSC resolution which contains direct sanction to the individuals in accordance with the national interests, especially related to the national financial and monetary regulations. The Singapore Financial Authority is fully authorized to suspend the implementation of the UNSC Resolutions in the event of conflicting the financial and monetary regulations. ${ }^{39}$

The UN Act shall support the implementation of other national legislations. Previously, Singapore had enacted a number of national laws related to strategic trade control applicable to countries subject to sanctions from the UNSC Resolution through the Singapore Regulation of Imports and Exports Act (RIEA). Through the RIEA, a number of contraband materials, especially those related to the development of weapons of mass destruction, can be controlled for traffic. However, RIEA has not been able to reach out further to goods that are not specifically related to nuclear and radioactive materials, such as luxury goods. In addition, the UNSC Resolution

35 Statutes of the Republic of Singapore United Nations Act (Chapter 339: Act 44 of 2001), §2, https://sso.agc.gov.sg/Act/ UNA2001?ViewType=Pdf\&_=20171121015734.

36 Id. $\S 1(1) \& \S 2(2)$.

37 Id. $\$ 2(2)(\mathrm{A}) \&(\mathrm{~B})$.

38 Singapore is a dualist State. See J. Neo, Legal Pluralism in Centralist Singapore, in Debating Legal Pluralism and Constitutionalism: New Trajectories for Legal Theory in the Global Age 253-4 (G. Tusseau ed., 2020).

39 Singapore UN Act of 2001, §2(2). 
cannot cover the goods that are categorized as contraband material, but only transit in Singapore without trans-shipment or unloading of goods at ports in Singapore. In this case, the UN Act is present as a catch-all mechanism to assist the implementation of the strategic trade control implemented nationally by Singapore in accordance with the mandate given by the UNSC Resolution. ${ }^{40}$

As a result, the UN Act has prevented the conflict of constitutional legitimacy, as a bridge for Singapore to directly apply the UNSC Resolutions to regulate the rights of individuals under national jurisdiction. In this regard, the UN Act has encouraged Singapore's adherence to the UNSC Resolutions without the Parliament consultation. It finally becomes a legal basis for the relevant Ministries or Agencies in Singapore to implement it at the national level. ${ }^{41}$

\section{The US}

The US Congress authorizes the President to implement the UNSC Resolutions under the 1945 United Nations Participation Act (UNPA). ${ }^{42}$ In the US, the UNSC Resolutions are integrated into the domestic legal order through Executive Orders. ${ }^{43}$ Actually, the US merges the implementation of Resolutions 1267 and 1337 in Executive Order 13224. The Executive Order can be reviewed by the domestic courts regarding the violation of due process of law before the national court. ${ }^{44}$ Nevertheless, in the cases of Aqeel Abdulaziz Al-Ageel, The Global Relief Foundation and Al Haramain Islamic Foundation, whose claims were submitted on the ground of violation of due process of law before the national court for the inclusion of their names in the consolidated list of 1267 , their assets were frozen without prior notification. ${ }^{45}$

The District Court ruled that the existence of unilateral evidence and the lack of a pre-appropriation hearing were constitutional. In Holy Land Foundation v. Ashcroft, the court justified that the absence of pre-confiscation of assets was intended to protect the interests of the government, the special need for very fast action, and that the initiator of the confiscation was a responsible official having special authority to do

$40 \quad I d . \S 2(1)$.

41 Id.

42 The United Nations Participation Act of 1945 [Chapter 583 of the 79th Congress; Approved December 20, 1945; Amended through P.L. 114-323 on Dec. 16, 2016].

43 Id. §5(a). For details, see M. Malloy, United Nations Participation Act (1945), Encyclopedia.com, https://www. encyclopedia.com/history/encyclopedias-almanacs-transcripts-and-maps/united-nations-participation-act-1945.

44 W. Diaz, Dualist, But Not Divergent: Evaluating United States Implementation of the 1267 Sanctions Regime, 5 LIBERTY U. L. REV. 348 (2011).

45 Id. at 357-9. See also Al-Aqeel v. Paulson, 568 F. Supp. 2d 64, 72 (D. D.C. 2008); Global Relief Found., Inc., v. O’Neill, 207 F. Supp. 2d 779 (N.D. Ill. 2002). 
so. ${ }^{46}$

In the US, it is not uncommon to find the UNSC Resolutions invoked to expand the range of domestic economic sanctions to include individuals or corporations outside their jurisdiction. ${ }^{47}$ The US Congress also enacted the International Emergency Economic Powers Act (IEEPA) which gives absolute authority to the government to freeze the assets of individuals or corporations that are domiciled in the US national jurisdictions. ${ }^{48}$ The IEEPA is widely used for freezing the property of individuals or corporations linked to Iran, in retaliation for the 1979 diplomatic hostage of the US Embassy in Tehran. ${ }^{49}$

The IIEPA has also been applied to foreign individuals or corporations related to Iraq in the 1990s and the economic sanctions of the UNSC related to organisations or entities involved in terrorism, such as the Taliban and Al-Qaeda. ${ }^{50}$ The IEEPA has committed the US to impose economic sanctions as a means of coercive measures based on Article 41 of the UN Charter. In the US, asset freezing can be carried out on all properties in the US national jurisdictions even if the individual or corporation is not domiciled in the US territory. It is considered as an administrative action. To date, the US President has set at least 22 Executive Orders for economic sanctions. Nevertheless, there has been neither a lawsuit against the Treasury, nor controversy in individual freedom or human rights in this course.

\section{E. Australia and the EU}

Australia has a UN Charter Act which stipulates that the implementation of targeted sanctions must not leave the procedural justice as adopted by the common law system. ${ }^{51}$ Meanwhile, the European Court of Justice (ECJ) in the case of Kadi $v$ Council (Kadi II) ruled that the violation of the due process of law in Resolution 1267 was contrary to the "...constitutional guarantee stemming from the EC Treaty as an autonomous legal system which is not to be prejudiced by an international

Diaz, supra note 44, at 357. See also Holy Land Found for Relief \& Dev. v. Ashcroft, 333 F.3d 156, 164 (D.C. Cir. 2003).

47 IEEPA § 1701. It states: "Any authority granted to the President by section 1702 of this title may be exercised to deal with any unusual and extraordinary threat, which has its source or substantial part outside the United States, to the national security, foreign policy, or economy, of the United States, if the President declares a national emergency with respect to such threat."

48 Id.

49 Id.

$50 \quad I d$.

51 UN Charter Act $\S \S 15-16$. See also S. Tully, Implementing Targeted Sanctions in Australia: A Role for Procedural Fairness, 16(1) Murdoch U. E-J. L. 125 (2009). 
agreement." ${ }^{, 52}$ In the previous decision (Kadi I) by the Court of First Instance (CFI) of the ECJ in 2005, the Court stated that UN member states should respect the UNSC Resolutions based on customary international law. ${ }^{53}$ CFI does not even have "jurisdiction to indirectly review the validity" of the UNSC Resolutions. ${ }^{54}$ However, it is found in the court ruling that CFI has the authority to examine, although indirectly, the validity of the UNSC Resolutions related to jus cogens, which is understood as the highest body of public rules of international law binding on all subjects of international law, including the UN body, which is not possible to reduce. ${ }^{55}$

\section{F. Switzerland}

In line with the decision of Kadi I, the Swiss Federal Court in the Youseff Mustafa Nada case rejected Nada's lawsuit being added to the Consolidated List because of his involvement with A1 Taqwa Management SA, which was suspected of supporting terrorist activities. ${ }^{56}$ The Swiss Federal Court prohibited him from leaving residence in the Campione d'Italia and got his assets frozen. The Swiss Federal Court stated that it has the authority to cancel the Switzerland's implementation of the regulations on the UNSC Resolutions contrary to the jus cogens. ${ }^{57}$ However, there was no violation of jus cogens in Nada's case, so that Switzerland was under obligation to enforce Resolution $1267 .^{58}$

In the case of Sayadi and Vinck, two Belgian nationals were placed in the Resolution 1267 blacklist by virtue of their positions leading the Foundation Secours International by the Belgian government without trial. In this case, the UN Human Rights Committee (HRC) found that the list was premature and therefore illegal. ${ }^{59}$ Belgium then had to remove the names of Sayadi and Vinck from the list and

52 Kadi v. Council (Kadi II), ๆ 316, 2008 E.C.R. I-6351, 2008 ECJ EUR-Lex LEXIS 1954 (Sept. 3, 2008). See also S. Morano-Foadi \& S. Andreakis, Protection of Fundamental Rights in Europe: The Challenge of Integration 156 (2020); Genser \& Barth, supra note 6, at 3.

53 Id.Kadi v. Commission (Kadi I), ๆ 181, 2005 E.C.R. II-3659, 2005 ECJ EUR-Lex LEXIS 673. See also Genser \& Barth, supra note 6, at 12.

54 Kadi I, ๆ 221.

55 Id. $ๆ 226$.

56 Youssef Nada v. State Secretariat for Economic Affairs and Federal Department of Economic Affairs (Nada), Administrative appeal judgment, Case No 1A 45/2007; ILDC 461 (CH 2007); BGE 133 II 450 (Nov. 14, 2007). See J. Reich, Due Process and Sanctions Targeted against Individuals pursuant to U.N. Resolution 1267 (1999), 33 YALE J. INT'L L. 507-8 (2008).

57 Nada, $i d$. ๆ 467.

58 Id. $\uparrow 450$. See also Reich, supra note 56, at 508.

59 UN Human Rights Comm., Sayadi v. Belgium (Sayadi), Commc'n No. 1472/2006, qฯ 2.3-3.1, U.N. Doc. CCPR/C/94/ D/1472/2006 (2008), https://undocs.org/en/CCPR/C/94/D/1472/2006. 
compensate them. Furthermore, Belgium is also obligated to ensure that similar violations will not occur in the future. ${ }^{60}$ The HRC ruled that even though it has jurisdiction to assess the alleged violations of the UN Charter, it has no competency to assess whether the national actions taken in the implementation of the UNSC Resolutions are compatibility with the International Covenant on Civil and Political Rights (ICCPR). The HRC asserted that it is the guarantor of the rights protected by the ICCPR, which is thus authorized to consider the extent to which obligations imposed on States parties by the UNSC resolutions may justify breaches of the Covenant. $^{61}$

\section{G. The UK}

In the case of R (Al-Jedda) v. Secretary of State for Defense, ${ }^{62}$ the British House of Lords held that Resolution 1546, which allowed Multi-National Forces operating in Iraq to detain individuals on security grounds, would take precedence over the UK's obligation to respect the due process of law guaranteed under the European Convention on Human Rights. ${ }^{63}$ The House of Lords determined that the conditions for the prevalence of Resolution 1546 were met. However, the House of Lords held that the powers conferred by the Security Council should be exercised in such a way that the rights of detainees are not violated to a greater degree than would be required in such detention. ${ }^{64}$ Baroness Hale of Richmond concluded that, although the UNSC Resolution may override the UK's commitment to the due process of law guaranteed by the European Convention on Human Rights, the House of Lords affirmed that "the right is qualified, but not displaced."

All in all, these cases would reaffirm that the UNSC Resolutions do not permanently override member states' commitments to the protection of fundamental human rights. Instead, they clarifies the minimum standard of treatments in the protection and fulfilment of human rights regarding the implementation of UNSC Resolutions. ${ }^{66}$ The State practices show that they are selectively approaching to the UNSC Resolutions based on individual or corporate rights and obligations more than before in line with their national interests.

60 Id. See also Willis, supra note 9, at 694.

61 Id.Sayadi, supra note 59, ๆ 6.1 .

62 Id.R v. Sec'y of State for Defense, [2007] UKHL 58, [2008] 1 A.C., at 332.

63 Id. at 354-5.

64 Id. at 355.

65 Id. at 376.

66 Supra note 9, at 693-4. 


\section{Indonesia's Practice in Implementing the UNSC Resolutions}

As of today, it is very much unclear where the international law, including the UNSC Resolutions, fits in the Indonesian legal system. The Indonesian Constitution is still silent on the matter of international law. Indonesian Law No. 12 of 2011 [Formation of Laws] does not mention the existence of international law. ${ }^{67}$ It is undecided whether Indonesia is monist or dualist in terms of incorporating international law into its national law. ${ }^{68}$

From the authors' observation, Indonesia's practice in implementing the UNSC Resolutions has been very casuistic. Indonesia has no legal umbrella for implementing the UNSC Resolutions. Instead, Indonesia implements Resolution 1267 through Law No. 9 of 2013 on the Prevention and Eradication of Criminal Acts of Terrorism Financing as well as the Joint Ministerial Regulation No. 231 of 2015 on Inclusion of the Identity of Persons and Corporations in the List of Suspected Terrorists and Terrorist Organisations and the Immediate Blocking of Funds Belonging to Persons or Corporations Listed in the List of Suspected Terrorists and Terrorist Organisations. ${ }^{69}$ The UNSC Resolution 1373 was implemented through Joint Regulation No. PER-01/1.02/PPATK/02/15 which enforces an asset freezing effort against individuals or corporations involved in terrorism. Indonesia has also implemented the UNSC Resolution 1535 which requires UN member States to form a Counter-Terrorism Committee Executive Directorate (CTCED) to monitor the implementation of Resolution 1373 through Presidential Decree No. 46 of 2010 on the National Agency for Countering Terrorism. All these legal instruments are intended to address the vulnerabilities disputed under its constitutional law. ${ }^{70}$

However, it is important to underline that none of these legal instruments refer to the UNSC Resolution as the basis for consideration in their enactment. For example, although Chapter VII of Law No. 9 of 2013 regulates the List of Suspected Terrorists and Terrorist Organisations (DTTOT) as required by Resolution 1267 and its derivatives, the "considering..." and "acknowledging..." sections of this law do not refer to Resolution 1267 and its derivatives at all. Rather, they refer to the

\footnotetext{
67 Id.S. Butt, The Position of International Law within the Indonesian Legal System, 28 Emory InT'L L. Rev. 3 (2014). See also Sefriani, Hukum Internasional suatu pengantar [International Law: An Introduction] 84-90 (11th ed. 2021). 
International Convention for the Suppression of the Financing of Terrorism 1999 which has been municipalized by Law No. 6 of 2006. The same condition occurs in other legal instruments above mentioned. Therefore, these legal instruments are not a form of direct implementation of the UNSC Resolutions in Indonesia. ${ }^{71}$

As per the consolidated list dated November 19, 2018, there were 265 individuals and 83 entities affiliated with Al Qaeda and ISIS (AQSI), 26 of which were Indonesian citizens along with five Indonesian entities. ${ }^{72}$ This list was later adopted by Indonesia in the DTTOT in accordance with Law No. 9 of 2013. It is not stagnant, limited to six months, and extendable twice for three months each. ${ }^{73}$ Article 32 of Law No. 9 of 2013 states that a person or a corporation that objects the inclusion of their identity in the DTTOT may request a determinative order to remove their identity from the list to the Central Jakarta District Court. ${ }^{74}$ This mechanism for filing an objection and removing identity from the DTTOT through an open examination procedure changes the direction of eradicating terrorism in Indonesia to be more transparent and independent as it no longer stipulates a list based on that issued by the UN alone. ${ }^{75}$

Nonetheless, Indonesia has no certain legal rules to implement the UNSC Resolution. Even the North Korean vessel, the MV Wise Honest-which allegedly violated the UNSC Resolutions 1718 (2006), 1874 (2009), 2087 (2013) and 2094 (2013) -was arrested, prosecuted, and fined for IDR 400 million for violating Law No. 17 of 2018 on Shipping and Law No. 6 of 2011 on Immigration, not for violation of the UNSC Resolutions. ${ }^{77}$ The Court's decision did not even address its relation to the UNSC Resolution in any ways. The vessel was then handed over to the US authorities upon MLA request for the investigation process of alleged money laundering crime and the violations of those UNSC Resolutions. Although the North Korean vessel was eventually handed over to the US on April 12, 2019, it did not actually meet

71 Indonesian Ministry of Foreign Affairs, Tinjauan Atas Kerangka Akademik Penerapan Resolusi DK PBB dalam Hukum Nasional [Overview of the Academic Framework Implementation of the UNSC Resolutions in National Law] $1-16(2020)$.

72 Id.

73 Indonesian Law No. 9 of 2013 on Terrorism Financing, art. 31.

74 Id. art. 32.

75 Fabian Januarius Kuado, Keputusan Penetapan Organisasi Teroris melalui Pengadilan Diapresiasi [Decision on Determination of Terrorist Organizations through Court Appreciated], KomPAs, Mar. 3, 2017, https://nasional.kompas. $\mathrm{com} / \mathrm{read} / 2017 / 03 / 30 / 07273901 /$ keputusan.penetapan.organisasi.teroris.melalui.pengadilan.diapresiasi.

76 Resolution 2270 (2016) decided: "Expressing gravest concern at the nuclear test conducted by the Democratic People's Republic of Korea (DPRK) on 6 January 2016 in violation of resolutions 1718 (2006), 1874 (2009), 2087 (2013) and 2094 (2013), and at the challenge such a test constitutes to the Treaty on Non-Proliferation of Nuclear Weapons (NPT) and to international efforts aimed at strengthening the global regime of non-proliferation of nuclear weapons, and the danger it poses to peace and stability in the region and beyond." For detail, see U.N. Doc. S/RES/2270 (2016), 29.

77 Supra note 1. 
the principle of double criminality as is generally required in MLA request. Under the Indonesian legal system, the violations of the UNSC Resolutions are not yet regulated, which causes the vessel to be tried for violating the Indonesian Shipping Law and Immigration Law instead.

A comprehensive legal umbrella is urgently necessary in order to stitch the legal loopholes and problems when the Indonesian Government is under the obligation to enforce the UNSC Resolution at the national level. A UN Act is also needed to regulate Indonesia's commitment to the UNSC Resolution by prioritizing the fulfilment of its national interests.

A new national legislation like the UN Act must be drafted considering all aspects including the criminal legality, sustainability, availability as a national legal umbrella. Indonesia's UN Act should also pay attention to certain laws that have partially enforced a number of the UNSC Resolutions so far. Other State practices can be taken into consideration as the benchmark for Indonesia to comply with the international human rights instruments, as well as bridge the gap between the global security and the constitutional legitimacy in its national law. These practices will be a good reference for Indonesia. Regarding the technical transformation of the UNSC Resolutions or the approval of the House of Representatives, the Constitutional Court's decision No. 13/PUU-XVI/2018 on Judicial Review of Law No. 24 of 2000 on International Treaties can be referred to. When the UNSC resolutions pose broad and fundamental consequences related to the burden of state finances and/or require amendments or the formation of new laws, they need to be approved by the House of Representatives.

\section{Conclusion}

To date, Indonesia has not adopted a national legal instrument regarding the implementation of the UNSC Resolutions. Its practice on this matter is very casuistic, dragging-on, and legally uncertain. In case of the UNSC Resolutions 1267 and 1373 which imposed sanctions on those who were included in the consolidated list, Indonesia implemented them through Law No. 9 of 2013 on the Prevention and Eradication of the Crime of Terrorism Financing; Joint Ministerial Regulation No. 231 of 2015 on Inclusion of the Identity of Persons and Corporations in the List of Suspected Terrorists and Terrorist Organisations and the Immediate Blocking of Funds Owned by Persons or Corporations Listed in the List of Suspected Terrorists 
and Terrorist Organisations; and Joint Regulations between the Indonesian Ministry of Foreign Affairs, the Indonesian National Police, the National Counter-Terrorism Agency, the Financial Transaction Reports and Analysis Centre, and the Supreme Court Case (No. PER- 01/1.02/PPATK/02/15) to enforce asset freezing against individuals or corporations involved in terrorism.

The UNSC Resolution 1535 which called for the establishment of a CounterTerrorism Committee Executive Directorate (CTCED) to monitor the implementation of Resolution 1373 has been enforced through Presidential Decree No. 46 of 2010 on the National Agency for Combating Terrorism. Considering the $M V$ Wise Honest case, Indonesia had difficulties in applying the UNSC Resolution to the vessel which entered the Indonesian territory due to the absence of any relevant legal rules.

It is indispensable for Indonesia to enact a comprehensive legal umbrella like a UN Act in order to efficiently enforce the UNSC Resolution containing targeted sanction at the national level. Such an Act will be a firm base not to repeat such a difficult situation like the $M V$ Wise Honest case. The Indonesian UN Act is expected to be a balancing solution between the obligation to comply with the UNSC Resolutions based on Article 25 of the Charter and that to comply with international human rights instruments for both the global security and the constitutional legitimacy in national law. The good practices of several countries which enforce the UN Act are to be deduced into technical rules in accordance with the requirements of the UNSC Resolutions. To address the extent to which parliamentary involvement is required in the technical regulations, the Constitutional Court's decision No. 13/PUUXVI/2018 on Judicial Review of Law No. 24 of 2000 on International Treaties may be a reference. Under a UN Act, the Indonesian House of Representatives can approve the enforcement of the UNSC Resolutions leading to broad and fundamental burden of state finances and/or requiring the amendments or formation of new laws. 